\title{
Nutrient Removal From Waste Water by Macrophytes - An Eco-Friendly Approach to Waste Water Treatment and Management
}

\author{
Sukhen Roy ${ }^{1}$, J. K. Biswas ${ }^{1} \&$ Sanjay Kumar ${ }^{2,3}$ \\ ${ }^{1}$ Department of Environmental Management, University of Kalyani, West Bengal, India \\ ${ }^{2}$ Department of Physics, B. R. Ambedkar Bihar University, Muzaffarpur, Bihar, India \\ ${ }^{3}$ Centre for Renewable Energy and Environmental Research, Muzaffarpur, Bihar, India \\ Correspondence: Sanjay Kumar, Centre for Renewable Energy and Environmental Research, Kafen Cottage, \\ Balughat, Muzaffarpur, Bihar, India. Tel: 91-943-1239820. E-mail: prof.kumars@gmail.com
}

Received: November 21, 2013 Accepted: March 4, 2014 Online Published: April 29, 2014

doi:10.5539/eer.v4n2p55

URL: http://dx.doi.org/10.5539/eer.v4n2p55

\begin{abstract}
Wastes are resources out of place. Waste management technique essentially includes nutrient removal for better uses through low cost sustainable eco-technology. In this paper, local indigenous Macrophytes (Ipomoea aquatic, Trapa, Nymphaearubra, and Pistia sp.) are investigated to assess their ability to reclaim nutrients and remove pollutants from sewage water in West Bengal. Nitrogen, phosphorus, BOD and salinity characteristics are investigated. These Macrophytes have adopted the environment and are found to grow in the vicinity of wastewater command areas. Results indicate that their potential is very high in removing nutrient pollutants cost-effectively. Nutrient thus removed can be used in cultivation process, reducing demand of chemical fertilizers.
\end{abstract}

Keywords: macrophytes, waste water management, pollutant, nutrient removal

\section{Introduction}

Urban India generates over 20 billion litres of sewage. Almost all of them ultimately find their way into aquatic ecosystem, seriously damaging them. Domestic wastes even pose eco-toxicological risk and health hazards when it unknowingly or accidently intermix with industrial effluents. At the same time, wastes are also resources out of place. It should not remain unutilized, but be returned to earth system for various human welfare activities through reclamation mechanisms and appropriate management strategies. About twenty different techniques are being applied all over the world (Welch, 1996; Debusk, Reddy, \& Clough, 1989) for waste water treatment. These include diversion of nutrient inputs and its treatment, inactivation of nutrients in input water, hypolimnetic aeration and artificial bubbling, chemical controlling and bio-manipulation approaches.

Nutrient diversion through constructed wetlands have become an important tool in developed countries for efficient management of wastewater during the last decade (Brix, 1994; Kadlec \& Knight, 1994; Knight, Kadlec, \& Reed, 1992). However, economic feasibility of such systems limits their application, especially in developing countries (Sun \& Qu, 1998). Traditional wastewater treatment plants are also not very cost-effective as they consume large amount of resources for construction and maintenance. Besides, they use hazardous chemicals and produce contaminated or even toxic sludge as a byproduct, thus are counterproductive in several cases (Etnier \& Guterstam, 1996).

During last decade, there have been major changes in the reclamation processes of wastewater, employing environment friendly low cost sustainable techniques such as integration of Macrophytes (Mitsch, 1996; Mohanty \& Sinha, 1999). In the aquatic environment, macrophytes are known for their capacity to purify waste water (Gumbricht, 1993; Ozimek, Van Donk, \& Gulati, 1993). Besides, they enlarge the matrix for many bacteria and zoobenthos and improve the condition for their living and reproduction. They also provide a sub-system to purify wastewater and promote the cycling of substances in water body (Busnardo, Gersberg, Langis, Sinicrope, \& Zedler, 1992; Poole, 1996; Yan \& Ma, 1998). Macrophytes base treatment system can be divided into free-floating ponds,submerged and constructed wetlands with emergent macrophytes depending on their structure and function. It can be classified in two groups, (a) Free floating and submerged species and, (b) constructed wetlan. The later is divided into subsystems - free water surface system and subsurface flow system. 
However, all these systems are primarily based on either monoculture or polyculture of vascular plants in shallow eutrophic water bodies which receive wastewater with a long residence time relative to that of conventional wastewater treatment systems.

In this paper, Macrophytes, Ipomoea aquatic, Trapa, Nymphaea rubra, and Pistia sp. are selected and investigated to assess their ability to reclaim nutrients (nitrogen and Phosphorus) and remove pollutants (BOD) from sewage water in West Bengal. These Macrophytes are indigenous, have adopted the environment and are found to grow in the vicinity of wastewater command areas.

\section{Materials and Method}

\subsection{Site Description}

Kalyani Sewage Treatment Plant caters to a population of 200,000 at Kalyani, West Bengal $\left(22^{\circ} 58^{\prime} 30^{\prime \prime} \mathrm{N}\right.$, $88^{\circ} 26^{\prime} 04^{\prime \prime E}$, elevation - 11 meters). Treatment ponds associated with Kalyani Sewage Treatment Plant are Anaerobic type and Facultative type. Domestic wastewater discharge contained both organic and inorganic solids in dissolved and suspended forms and is relatively dilute with $85-95 \%$ water. Preliminary investigation indicated $250-400 \mathrm{ppm}$ of organic $\mathrm{C}$ and $80-120 \mathrm{ppm}$ of total nitrogen, thus giving a C:N ratio of around 1:3. The composition is qualitatively different from industrial wastewater in which heavy metals and toxic chemicals dominate.

\subsection{Macrophytes Selection}

Following criteria is used in selecting macrophytes,

- adaptability to local climate;

- tolerance to adverse climatic conditions;

- tolerance to adverse concentration of pollutants;

- pollutants assimilative capacity;

- high rate of photosynthesis;

- high oxygen transport capability;

- resistance to pests/diseases;

- ease of management harvesting.

Based on these criteria, the macrophytes selected in the study are Ipomoea aquatic (Figure 1), Trapa (Figure 2), Nymphaea rubra (Figure 3), and Pistia sp. (Figure 4). Their observed growth in sewage disposal area is remarkable. Other properties are as follows;

Water Spianch (Ipomoea aquatica) - It is a semi-aquatic, tropical plant grown as a leafy vegetable in water or on moist soil. Its stems are 2-3 metres long and hollow, rooting is at the nodes. Leaf shape and size vary from typically sagittate (arrow head-shaped) to lanceolate, $5-15 \mathrm{~cm}$ long and $2-8 \mathrm{~cm}$ broad. The flowers are trumpet-shaped, $3-5 \mathrm{~cm}$ diameter, usually white in colour with a mauve centre. The flowers can form seed pods.

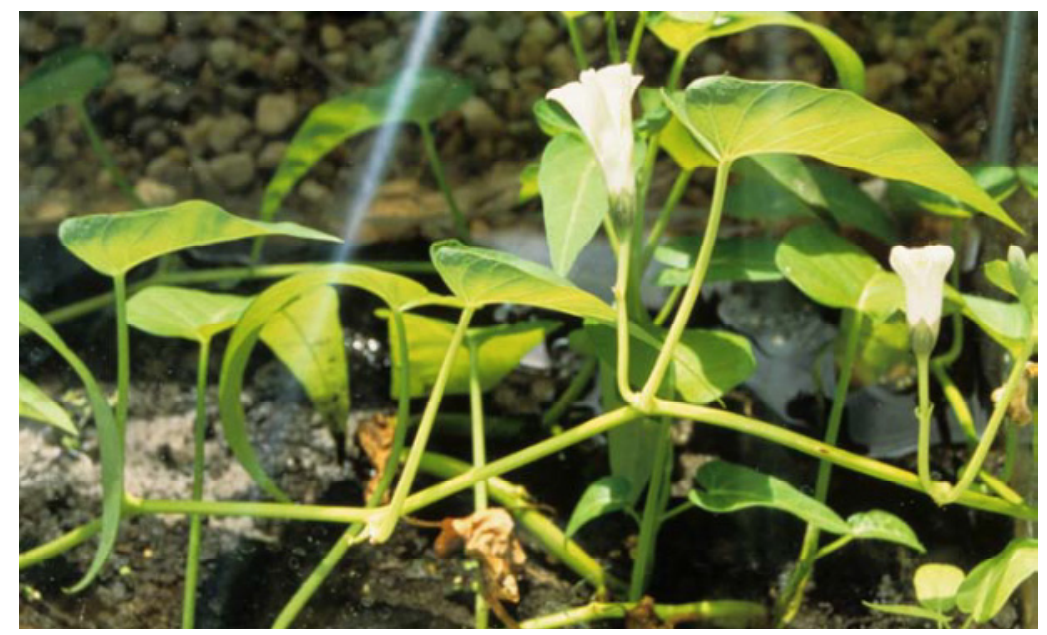

Figure 1. Water Spianch (Ipomoea aquatica) 
Trapa - Two species of trapa is found in Kolkata region: Trapa natans and Trapa bicornis. Both the species are native to warm temperate parts of Eurasia and Africa. It is a floating annual aquatic plant. It grows in slow-moving water. It can survive in 5 meters deep water body. They bear ornately shaped fruit containing a single very large starchy seed.

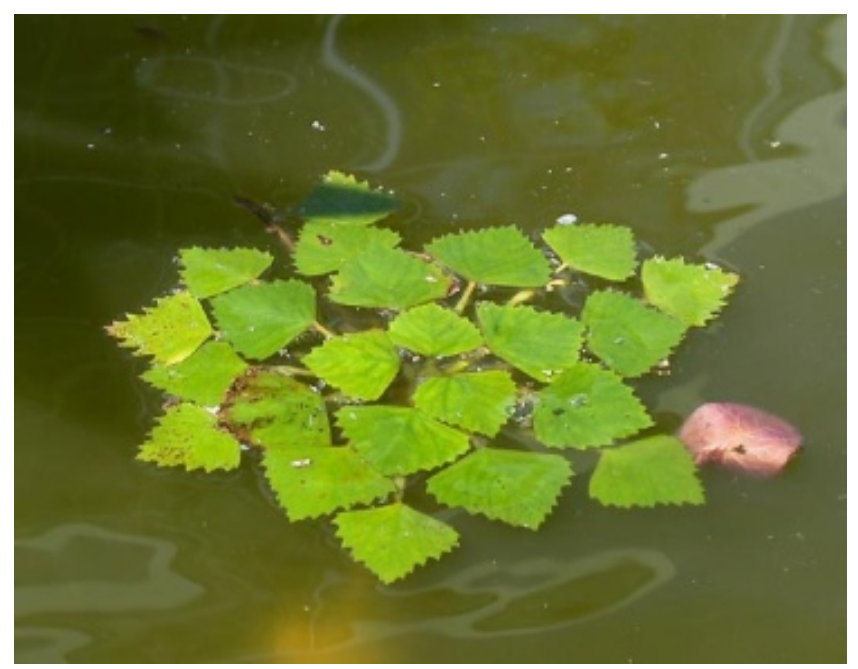

Figure 2. Trapa (Trapa natans and Trapa bicornis)

Pistia (Pistia stratiotes) - It is a perennial monocotyledon with thick, soft leaves that form a rosette. It floats on the surface of the water and its hanging roots remain submersed beneath floating leaves. Leaves $(\sim 14 \mathrm{~cm}$ long) have parallel veins and wavy margins, covered in short hairs forming basket-like structures, which trap air bubbles, increasing the plant's buoyancy. Flowers are dioecious. It can undergo asexual reproduction.

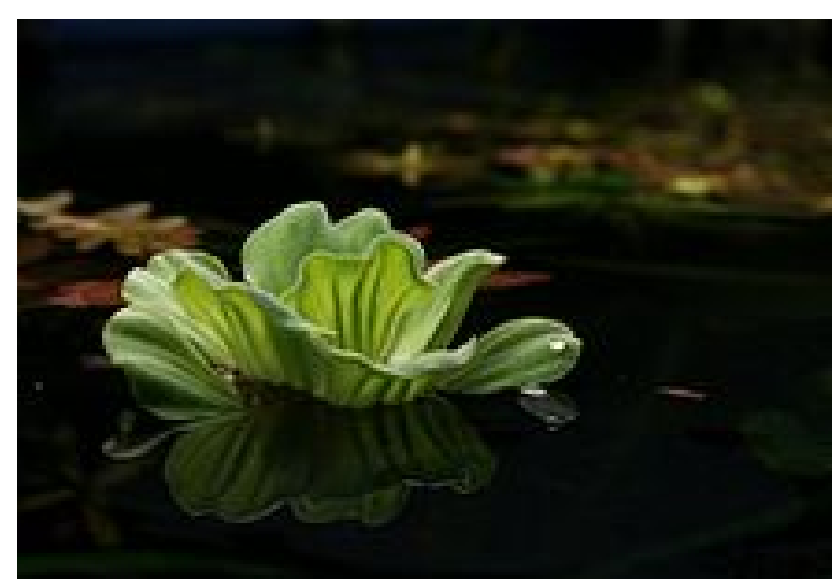

Figure 3. Pistia (Pistia stratiotes)

Water Lily (Nymphaea Rubra), family Nymphaeaceae: Its leaves have a radial notch from the circumference to the petiole in the center. It is closely related to Nuphar, another genus commonly called "lotus". However, its flower petals are much larger than the sepals and fruits are held above water level to maturity; in contrast with smaller sepals of Nuphar and underwater fruits. 


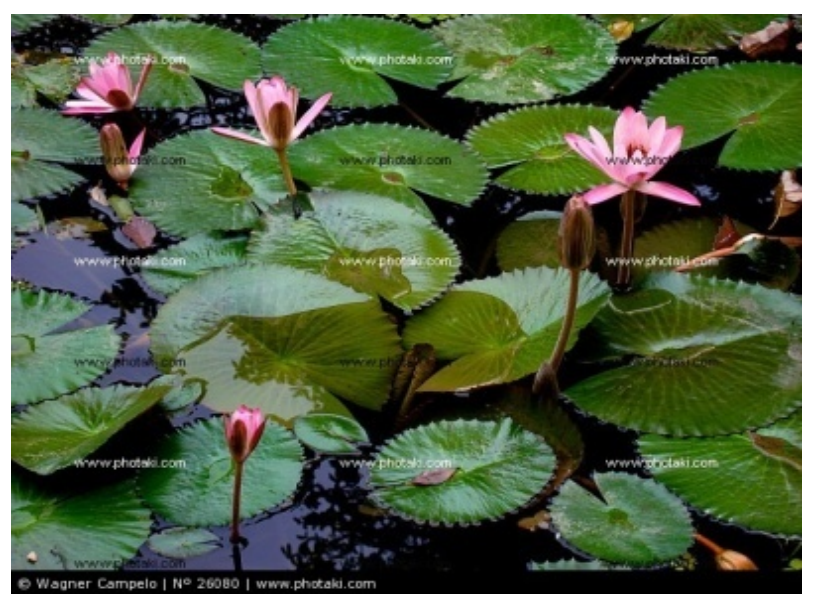

Figure 4. Water Lily (Nymphaea Rubra)

\subsection{Experimental Set up}

Sixteen sets of water container of capacity 20 lts and height $40 \mathrm{~cm}$ were prepared. 10 containers were used for facultative sample treatment and six for anaerobic sample treatment. $6 \mathrm{~cm}$ of the bucket were filled with mud from respective ponds to provide actual condition of growing macrophytes. Sewage water from facultative and anaerobic pond was collected. Containers with facultative and anaerobic muds were filled with 12.5 lts of respective sewage water collected. Two sets of container with facultative pond samples were planted with Ipomoea aquatic, Trapa (Trapa natans and Trapa bicornis mixed), Pistia stratiotes, Nymphaea rubra, and similarly, two sets of container with anaerobic pond samples were planted with Ipomoea aquatic, and, Pistia stratiotes. Two sets of container with facultative and anaerobic sewage samples were used as indicators to discount possibility of other mechanisms such as photo-degradation etc. Table 1 shows the list of macrophytes used in various containers and their symbols. In anaerobic condition only two macrophytes showed potential of nutrient removal in initial experiments. These two species possibly increased aeration and absorption of nutrients. Evaporation of water is compensated with distilled water supplement. The study was carried out for thirty days in May-June 2013, and samples were collected on Day 0, 1, 3, 5, 7, 10, 15, 20 and Day 30. These samples were instantly analysed to collect data without any loss.

Nitrogen and Phosphorous contents were measured by UV Spectrophotometer, extracting very small amount of sample from the container. $\mathrm{pH}$ and salinity were measured with Eco Tester meter and PCS Tester 3. BOD was measured with WTW OXITOP IS-6 BOD bottles with digital display. Appropriate reagents for BOD, Nitrate, Nitrite, Ammonical Nitrogen and phosphate determination were used.

Table 1. List of macrophytes and respective ponds

\begin{tabular}{clc}
\hline Symbols & Pond Type & Macrophyte used \\
\hline AF & Facultative & ipomoea aquatica \\
BF & Facultative & trapa natans \\
CF & Facultative & NONE \\
DF & Facultative & nymphae rubra \\
EF & Facultative & Pistia sp. \\
AA & Anaerobic & ipomoea aquatica \\
CA & Anaerobic & NONE \\
EA & Anaerobic & Pistia sp. \\
\hline
\end{tabular}

\section{Results and Discussion}

Figures 5 and 6 , shows the variation of nitrite concentration in the containers. There is marginal decrease in nitrite concentration in the indicator container due to unknown factors. Even after discounting this marginal 
decrease, macrophytes are very effective in absorption of nitrites. In facultative pond, Ipomoea aquatic and Pistia stratiotes shows very high potential. 15 days is good enough to absorb over $65 \%$ of nitrite after discounting for other factors responsible for reduction in nitrite concentration. These two species are even more active in anaerobic ponds. Nitrite absorbed by the plant can be gainfully used as natural fertilizer.

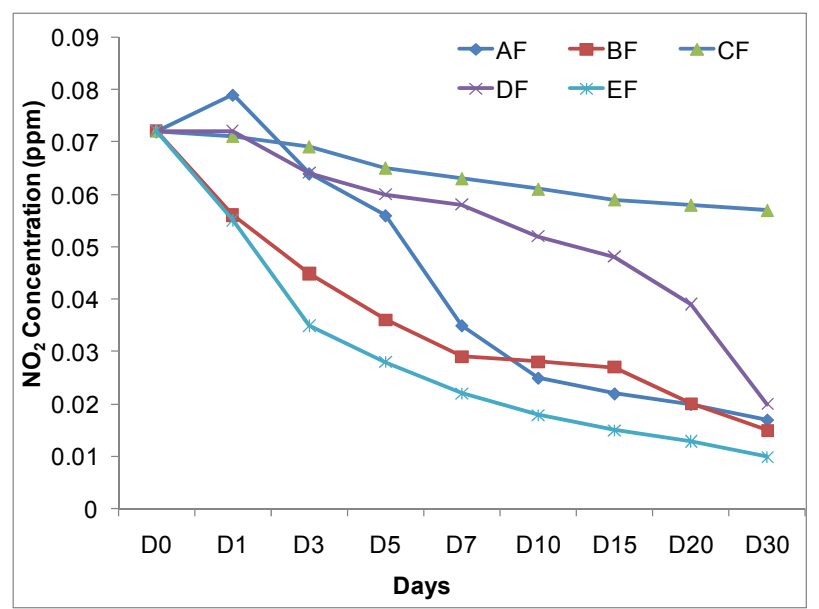

Figure 5. Variation of $\mathrm{NO}_{2}$ concentration (ppm) in facultative pond

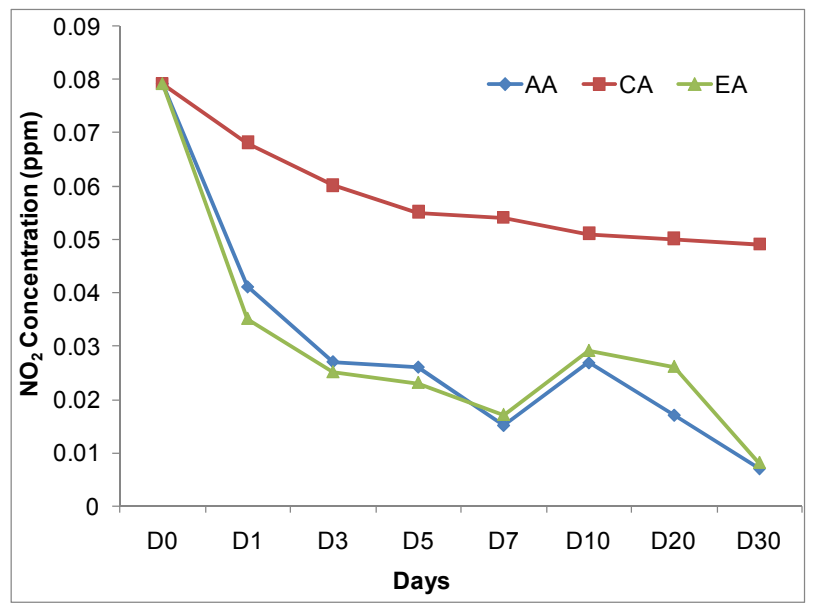

Figure 6. Variation of $\mathrm{NO}_{2}$ concentration (ppm) in anaerobic pond

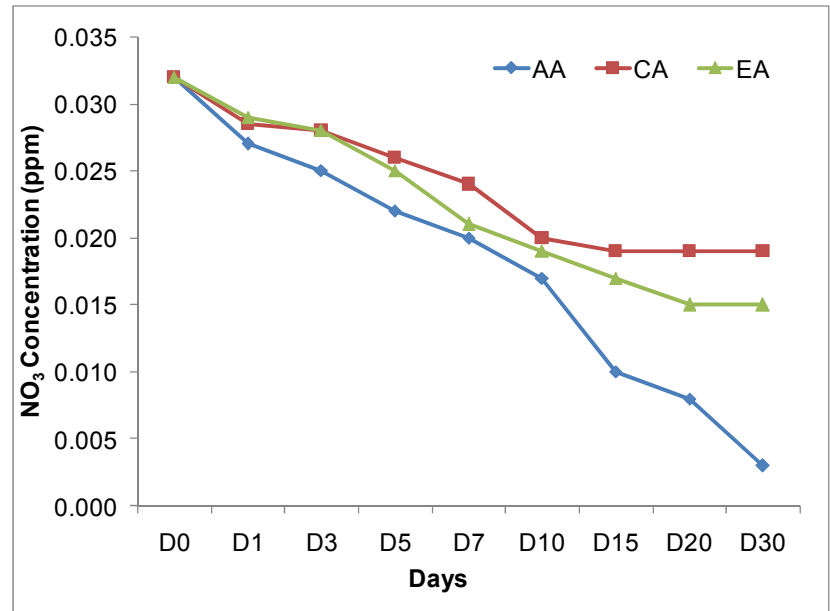

Figure 7. Variation of $\mathrm{NO}_{3}$ concentration (ppm) in facultative pond 


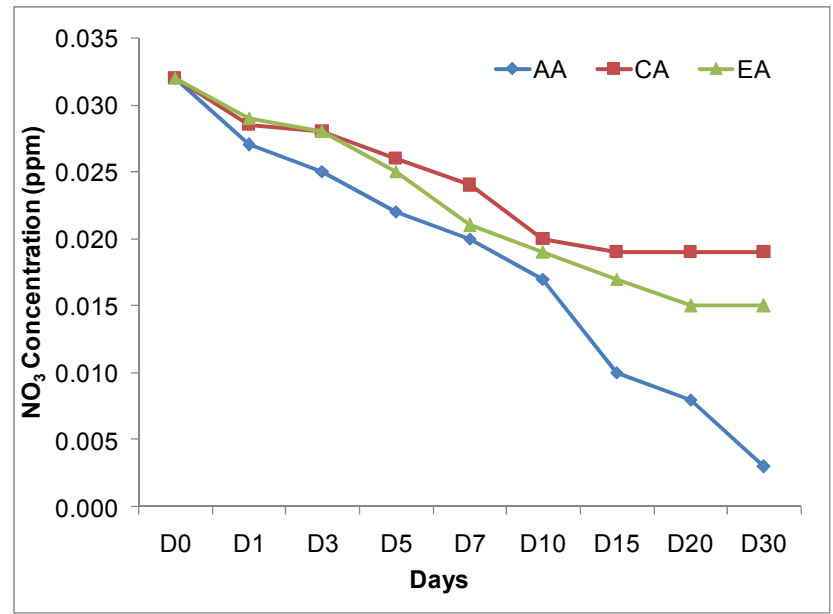

Figurer 8. Variation of $\mathrm{NO}_{3}$ concentration (ppm) in anaerobic pond

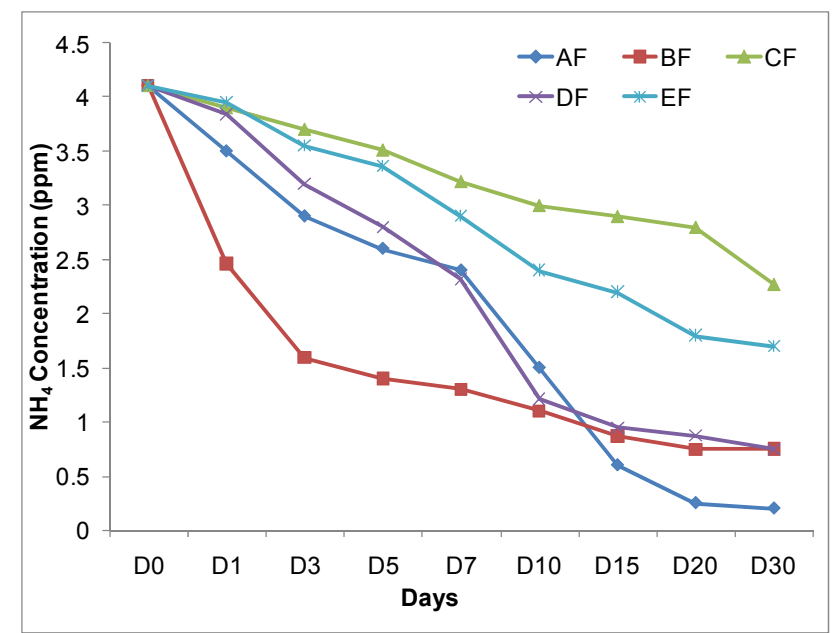

Figure 9. Variation of $\mathrm{NH}_{4}$ concentration (ppm) in facultative pond

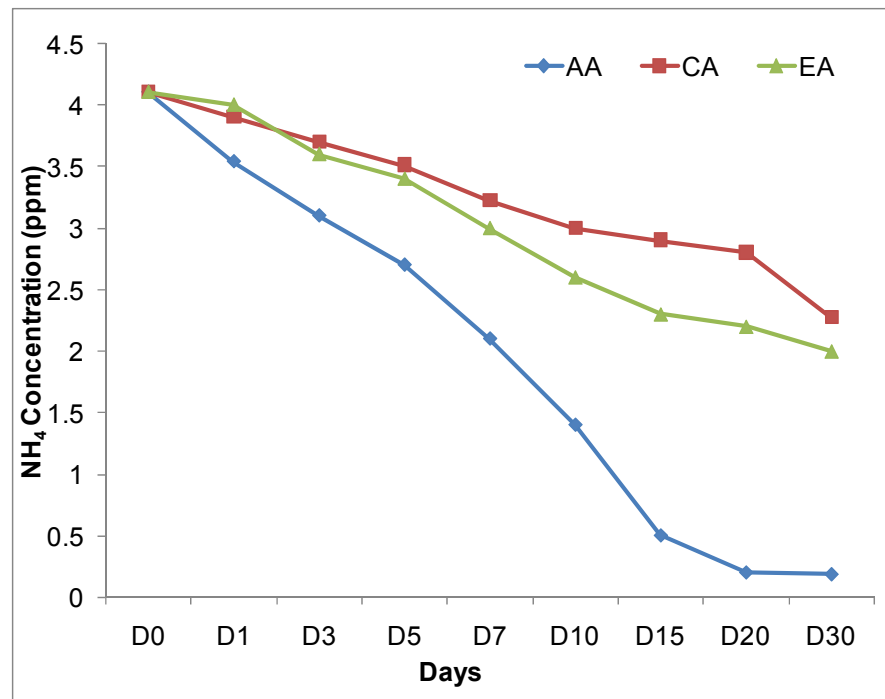

Figure 10. Variation of NH4 concentration (ppm) in anaerobic pond 


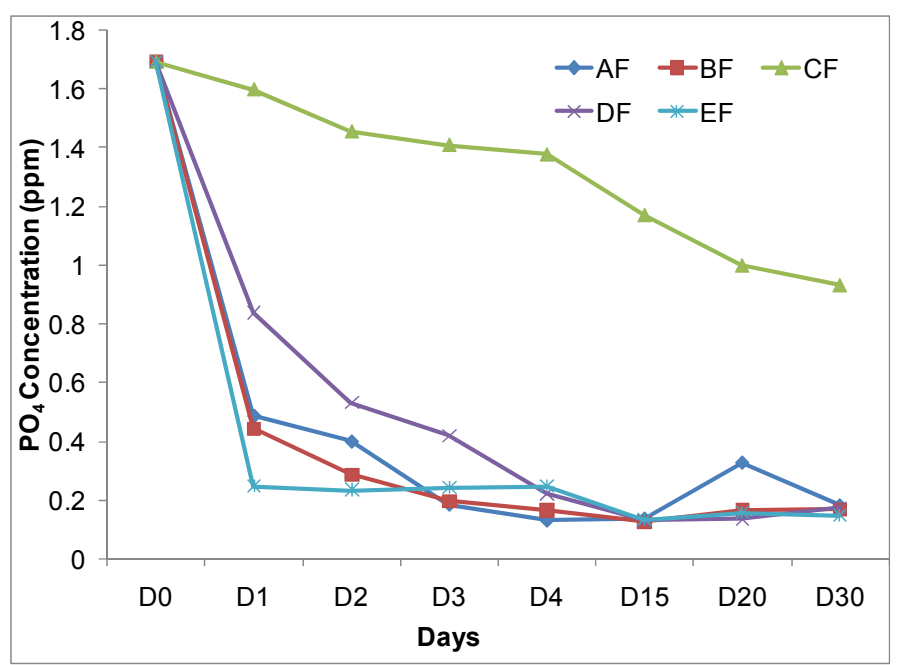

Figure 11. Variation of $\mathrm{PO}_{4}$ concentration (ppm) in facultative pond

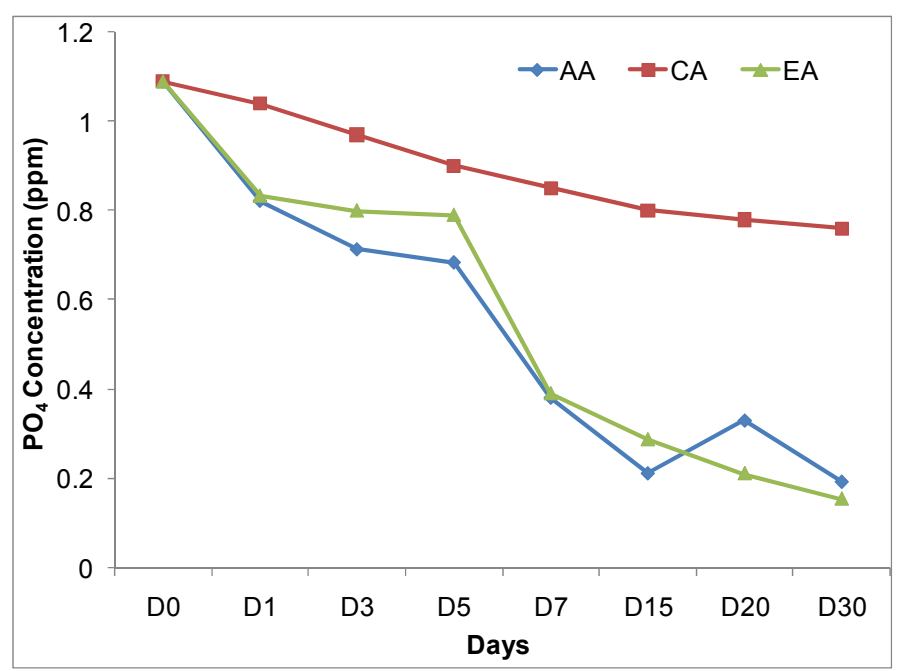

Figure 12. Variation of $\mathrm{PO}_{4}$ concentration (ppm) in anaerobic pond

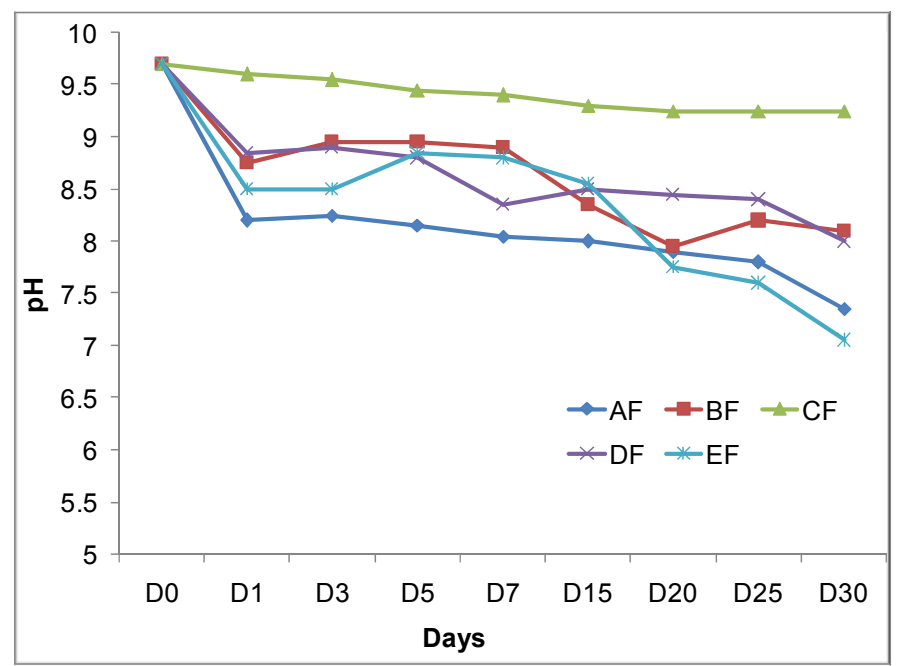

Figure 13. Variation of $\mathrm{pH}$ concentration in facultative pond 


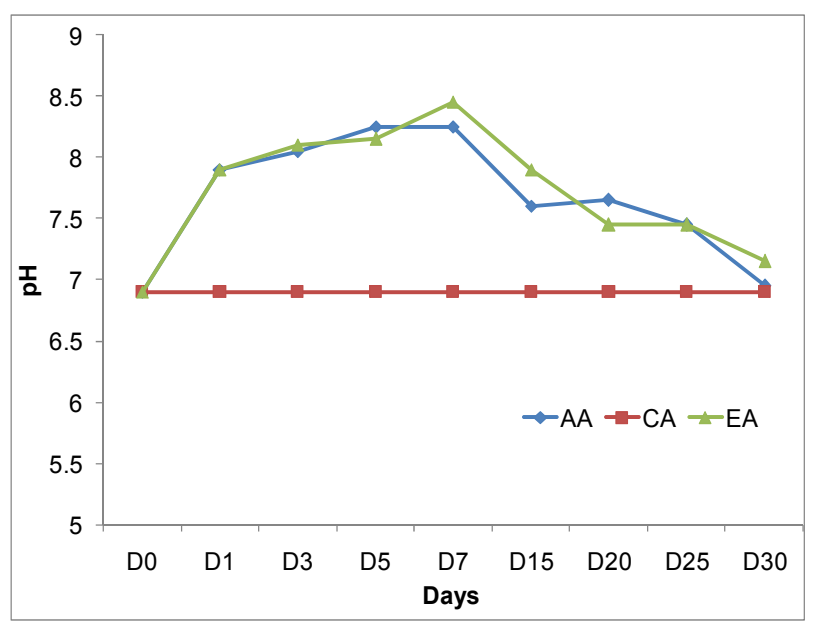

Figure 14. Variation of $\mathrm{pH}$ concentration in anaerobic pond

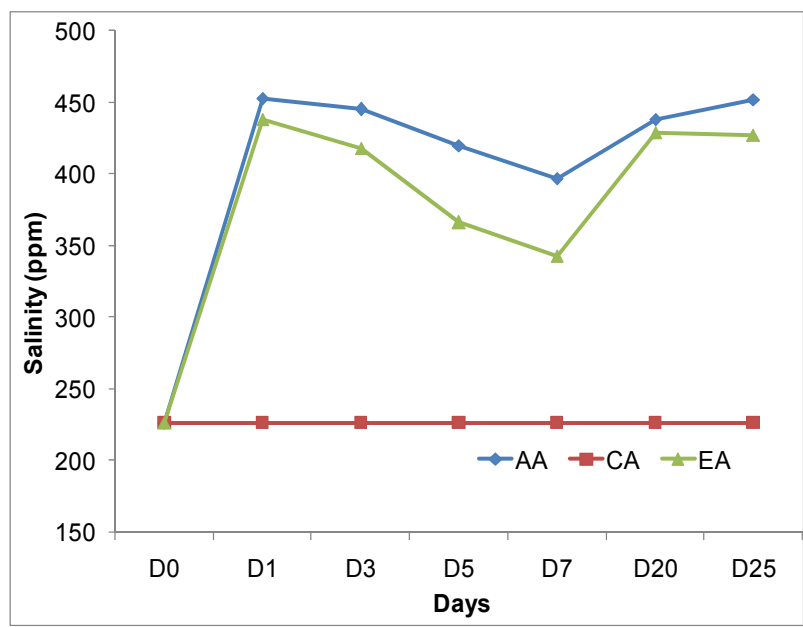

Figure 15. Variation of Salinity (ppm) in anaerobic pond

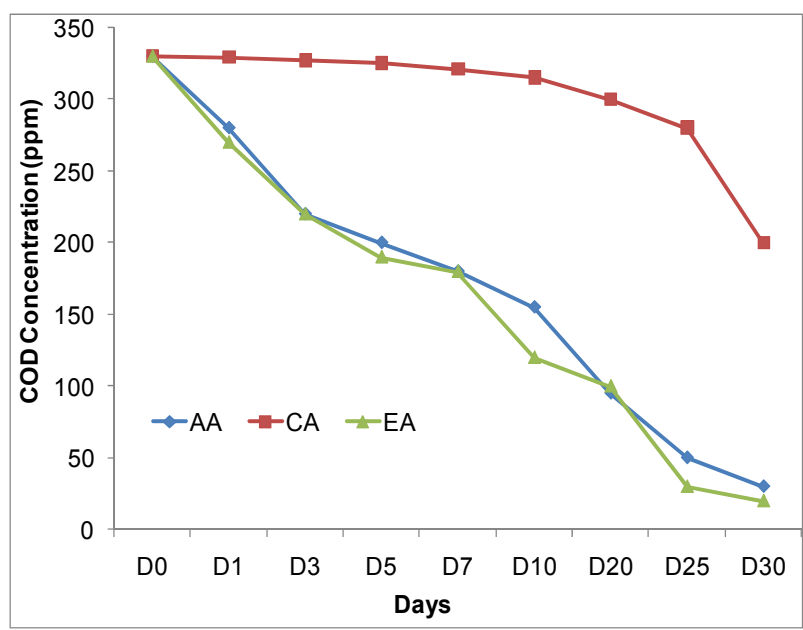

Figure 16. Variation of COD (ppm) in anaerobic pond

Figures 7, 8, 9 and 10, show reduction potential of $\mathrm{NO}_{3}$ and $\mathrm{NH}_{4}$ in Facultative and Anaerobic pond. Reduction in $\mathrm{NO}_{3}$ and $\mathrm{NH}_{4}$ concentration is a little bit slow. Significant reduction is observed in 15 days rather than 7 days as in case of $\mathrm{NO}_{2}$ reduction. Figures 11 and 12, show macrophytes' potential of $\mathrm{PO}_{4}$ absorption. In facultative 
pond, all the macrophytes show high potential of $\mathrm{PO}_{4}$ absorption. Nearly $80 \%$ is absorbed in first 4 days only. However, in anaerobic pond simple containers, it took much longer time to absorb $\mathrm{PO}_{4}, 15$ days or more. Absorption pattern is almost linear with time. Figures 13 and 14, shows variation of $\mathrm{pH}$ concentration in facultative and anaerobic pond samples. Variation in $\mathrm{pH}$ is not significant and shows a little erratic behavior. Pistia stratiotes and Nymphaea rubra reduces $\mathrm{pH}$ from 9.75 to 7.5 . However in anaerobic pond samples, there is hardly any change visible.

Figure 15 shows variation of salinity in anaerobic condition, which is increasing. However, BOD concentration changes significantly, from 335 to less than $40 \mathrm{ppm}$ (Figure 16). However it needed a period of 25 days. It is quite possible that in 25 days, BOD might have settled down as evident from indicator samples. However, still, macrophytes contribution of reducing BOD cannot be ignored.

\section{Conclusion}

Macrophytes (Ipomoea aquatic, Trapa, Nymphaearubra, and Pistia sp.) show robustness in removal of nutrient -pollutants for gainful application. Their effectiveness is depends types of pollutants, which provides leverage for waste management. Ipomoea aquatic and Pistia sp. are more effective in reducing pollutants from wastewater of municipal area.

\section{References}

Brix, H. (1994). Use of constructed wetlands in water pollution control: Historical development, present status, and future perspectives. Water Science and Technology, 30(8), 209-223.

Busnardo, M. J., Gersberg, R. M., Langis, R., Sinicrope, T. L., \& Zedler, J. B. (1992). Nitrogen and phosphorus removal by wetland mesocosms subjected to different hydroperiods. Ecological Engineering, 1, $287-307$. http://dx.doi.org/10.1016/0925-8574(92)90012-Q

Debusk, T. A., Reddy, K. R., \& Clough K. S. (1989). Effectiveness of mechanical aeration in floating aquatic macrophytes-based wastewater treatment systems. Journal of Environmental Quality, 18(3), 349-354. http://dx.doi.org/10.2134/jeq1989.00472425001800030019x

Etnier, C., \& Guterstam, B. (1996). Ecological engineering for waste water treatment. New York: CRC Press.

Gumbricht, T. (1993). Nutrient removal process in freshwater submersed macrophytes system. Ecological Engineering, 2(1), 1-30. http://dx.doi.org/10.1016/0925-8574(93)90024-A

Kadlec, R. H., \& Knight, R. L. (1996). Global Wetlands. Florida : CRC Press.

Knight, R. L., Kadlec, R. H., \& Reed, S. C. (1992). Wetlands for wastewater treatment database. Proceedings of $3^{\text {rd }}$ International Conf. on Wetland Systems for Water Pollution Control. Sydney, Australia.

Mitsch, W. J. (1996). Ecological engineering: a new paradigm for engineers and ecologists: Engineering within ecological constraints. Washington DC: National Academy Press.

Mohanty, R. K., \& Sinha, M. K. (1999). Use of aquatic macrophytes in water quality management. Fishing chimes, 18, 33-34.

Ozimek, T., Van Donk, E., \& Gulati, R. D. (1993). Growth and nutrient uptake by two species of Elodea in experimental conditions and their role in nutrient accumulation in a macrophytes dominated lake. Hydrobiologia, 251, 13-18. http://dx.doi.org/10.1007/BF00007159

Poole, W. (1996). Natural wastewater treatment with duckweed aquaculture, recycling resources, Ecological engineering for waste water treatment. Environment Research Forum, vols. 5-6, Switzerland: Transtec Publications.

Welch, E. B. (1996). Ecological Effects of Wastewater: Applied limnology and pollutant effects. London: Chapman and Hall.

Yan. J., \& Ma, S. (1991). The function of ecological engineering in environmental conservation in environmental conservation with some case studies from china. Ecological engineering for waste water treatment. Sweden: Gothenberg.

\section{Copyrights}

Copyright for this article is retained by the author(s), with first publication rights granted to the journal.

This is an open-access article distributed under the terms and conditions of the Creative Commons Attribution license (http://creativecommons.org/licenses/by/3.0/). 